J. Clin. Chem. Clin. Biochem.

Vol. 24, 1986, pp. $841-845$

(C) 1986 Walter de Gruyter \& Co. Berlin - New York

\title{
Phosphoglycerate Kinase Deficiency: Biochemical Studies on Hair Follicles
}

By A. C. Dijkstra, A. M. G. Vermeesch-Markslag, C. M. A. A. Goos, A. Miguel ${ }^{1}$ ) and A.J. M. Vermorken

Research Unit for Cellular Differentiation and Transformation, University of Nijmegen, Nijmegen, The Netherlands

(Received December 13, 1985/July 18, 1986)

Summary: A fluorimetric procedure for the determination of phosphoglycerate kinase in single human hair follicles is described. Enzyme studies on different parts of hair follicles after dissection show that the distribution of glucose-6-phosphate dehydrogenase matches that of phosphoglycerate kinase. Glucose-6phosphate dehydrogenase can therefore be used as a reference enzyme to compensate for differences in hair follicle sizes. It was shown that the variation in the values found in individual hair follicles is improved by relating phosphoglycerate kinase to glucose-6-phosphate dehydrogenase activity. In areas of the world where glucose-6-phosphate dehydrogenase deficiency occurs frequently, an autosomally inherited reference enzyme may be preferred. It is shown that 6-phosphogluconate dehydrogenase is useful in this respect. Upon storage a gradual drop in the activity of all three enzymes was observed, but the rate of decrease was about equal: the enzyme activity ratio was, therefore, almost unaffected for a period of one week. This allows the determination of phosphoglycerate kinase even in mailed hair follicles.

\section{Phosphoglyceratkinase-Mangel: Biochemische Untersuchungen an Haarfollikeln}

Zusammenfassung: Ein fluorimetrisches Verfahren zur Bestimmung von Phosphoglyceratkinase in einzelnen Haarfollikeln des Menschen wird beschrieben. Enzymuntersuchungen an verschiedenen Teilen von Haarfollikeln nach Dissektion zeigen, daß die Verteilung von Glucose-6-phosphatdehydrogenase der von Phosphoglyceratkinase entspricht. Glucose-6-phosphatdehydrogenase kann deshalb zur Kompensation von Unterschieden in der Größe der Haarfollikel als Referenzenzym benutzt werden. Es wird gezeigt, daß Unterschiede in den für einzelne Haarfollikel gefundenen Werten verbessert werden können, wenn Phosphoglyceratkinase auf die Aktivität von G̣lucose-6-phosphatdehydrogenase bezogen wird. In Gegenden der Welt, in denen Glucose-6phosphatdehydrogenase-Mangel häufig vorkommt, kann ein autosomal vererbtes Referenzenzym vorgezogen werden. Es wird gezeigt, daß hierfür 6-Phosphogluconatdehydrogenase brauchbar ist. Bei Aufbewahrung wurde eine allmähliche Abnahme der Aktivität aller drei Enzyme beobachtet, der Grad der Abnahme war aber etwa gleich: Deșhalb war das. Verhältnis der Enzymaktivitäten für die Periode einer Woche meist unbeeinflußt. Dies erlaubt die Bestimmung von Phosphoglyceratkinase auch in versandten Haarfollikeln.

\section{Introduction}

Phosphoglycerate kinase (EC 2.7.2.3) deficiency is a recessive X-linked inborn error of metabolism which may lead to haemolytic anaemia and mild mental retardation $(1,2)$. In this respect the disorder resem-

1) A. Miguel was a visiting fellow from the Department of Genetics, Faculty of Science, University of Palma de Mallorca, Spain.

J. Clin. Chem. Clin. Biochem. / Vol. 24, 1986 / No. 11 bles another inborn error of metabolism, glucose-6phosphate dehydrogenase deficiency, better known as favism (3). Diagnosis of hemizygotes with phosphoglycerate kinase deficiency is possible by the quantitative assay of the enzyme in erythrocytes (4). However, female heterozygotes may escape detection since overlap between heterozygous, homozygous and hemizygous individuals occurs (1). 
In cloncs of cultured fibroblasts derived from a female, heterozygous for phosphoglycerate kinase deficiency, a mosaic of phosphoglycerate kinase deficient and normal values was measured, whereas a reference enzyme displayed normal activities in the cells (5). Suspected carriers can be screened using this approach. Unfortunately, this is not very practical since it is relatively time-consuming and expensive. The above-mentioned experiments demonstrate, however, that the information for the enzyme phosphoglycerate kinase is present on that part of the $\mathrm{X}$-chromosome undergoing lyonisation (lyonisation means that per cell only the paternal or maternal X-chromosome is expressed (6)). Since most human hair follicles are of clonal origin, the hair follicle will in this respect behave as cell clones (7). Hair follicles have already been shown to be convenient tissue specimens for detection of several other X-linked enzyme deficiencies $(8,9,10)$.

In the present paper we describe a quantitative assay for phosphoglycerate kinase in single hair follicles, which fulfils the criteria for the above-mentioned purpose.

\section{Materials and Methods}

Chemicals

Glucose-6-phosphate, 3-phosphoglycerate, adenosine triphosphate (ATP), nicotinamide adenine dinucleotide (reduced form) (NADH), nicotinamide adenine dinucleotide phosphate $\left(\mathrm{NADP}^{+}\right)$, glyceraldehyde phosphate dehydrogenase, 6-phosphogluconate and 6-phosphogluconate dehydrogenase were obtained from Boehringer (Mannheim, FRG). 2 Amino-2-methyl1,3-propanediol, ethylenediamine tetra-acetic acid (EDTA), Tris(hydroxymethyl)aminomethane, Triton X100 and bovine serum albumin were obtained from Sigma (St. Louis, USA) Magnesium chloride was obtained from Merck (Darmstadt, FRG).

\section{Enzyme assays}

Human hair follicles were plucked at random from several areas of the scalp; those with a visible bulb and sheath (anagen phase) were cut off just above the sheath and immersed in $55 \mu \mathrm{l}$ Triton X100 $(0.1 \mathrm{~g} / \mathrm{l})$ for 60 minutes at room temperature. Aliquots $(15 \mu \mathrm{l})$ of the hair follicle lysate were used for the phosphoglycerate kinase, glucose-6-phosphate dehydrogenase and 6-phosphogluconate dehydrogenase assay.

The assay procedure for phosphoglycerate kinase was essentially the same as described by Beutler (3). The reaction was started by addition of $15 \mu \mathrm{l}$ hair follicle lysate to a $100 \mu \mathrm{l}$ incubation mixture, containing $0.3 \mathrm{~mol} / \mathrm{l}$ Tris- $\mathrm{HCl}(\mathrm{pH} 7.0), 10$ $\mathrm{mmol} / \mathrm{l}$ magnesium chloride, $8 \mathrm{mmol} / \mathrm{l}$ ATP (neutralized), 100 mmol/1 3-phosphoglycerate, $1 \mathrm{mmol} / 1 \mathrm{NADH}$ and 4000 units/l glyceraldehyde phosphate dehydrogenase. After an incubation period of 20 minutes at $30^{\circ} \mathrm{C}$, the reaction was terminated by addition of $800 \mu \mathrm{l} 0.02 \mathrm{~mol} / \mathrm{l}$ sodium hydroxide. The conversion of NADH to $\mathrm{NAD}^{+}$was determined by fluorescence spectroscopy at an excitation wavelength of $350 \mathrm{~nm}$ and an emission wavelength $460 \mathrm{~nm}$.
The glucose-6-phosphate dehydrogenase assay and the 6-phosphogluconate dehydrogenase assay were essentially the same as described earlier (10). In the glucose-6-phosphate dehydrogenase assay $15 \mu \mathrm{l}$ hair follicle lysate was added to $130 \mu \mathrm{l}$ incubation mixture containing $0.1 \mathrm{~mol} / 1$ 2-amino-2-methyl-1,3-propanediol (pH 8.6), $20 \mathrm{mmol} / 1$ glucose-6-phosphate, $2.5 \mathrm{mmol} / 1$ magnesium chloride, $10 \mathrm{mmol} / 1 \mathrm{NADP}+, 0.5 \mathrm{mmol} / 1$ EDTA, $0.5 \mathrm{~g} / \mathrm{l}$ bovine serum albumin and 300 milli-units 6-phosphogluconate dehydrogenase. In the 6-phosphogluconate dehydrogenase assay $15 \mu \mathrm{l}$ hair follicle lysate was added to $130 \mu \mathrm{l}$ incubation mixture containing $0.1 \mathrm{~mol} / \mathrm{l}$ 2-amino-2-methyl-1,3-propanediol (pH 8.6), $10 \mathrm{mmol} / \mathrm{l}$ 6-phosphogluconate, $2.5 \mathrm{mmol} / \mathrm{l}$ magnesium chloride, $5 \mathrm{mmol} / 1 \mathrm{NADP}+, 0.5 \mathrm{mmol} / 1 \mathrm{EDTA}$ and $0.5 \mathrm{~g} / 1$ bovine serum albumin. After an incubation period of 60 minutes at $37^{\circ} \mathrm{C}$ both reactions were terminated by addition of $800 \mu \mathrm{l} 0.02 \mathrm{~mol} / \mathrm{l}$ sodium hydroxide. Enzyme activity was measured as the formation of NADPH by fluorescence spectroscopy at an excitation wavelength of $350 \mathrm{~nm}$ and an emission wavelength of $460 \mathrm{~nm}$. Blank values in all three assays were obtained by adding $15 \mu \mathrm{l}$ Triton X100 (0.1 g/l) without hair follicle lysate to the incubation medium.

\section{Enzyme assays on dissected hair follicles}

15 single hair follicles obtained from normal individuals were dissected under a binocular microscope by cutting them just above, through the middle and just below the sheath. The different parts are referred to as upper sheath, lower sheath and bulb, respectively. Each hair follicle fraction was immersed in $55 \mu \mathrm{l}$ Triton X100 $(0.1 \mathrm{~g} / \mathrm{l})$ and assayed for phosphoglycerate kinase, glucose-6-phosphate dehydrogenase and 6-phosphogluconate dehydrogenase activity.

\section{Mailing of hair follicles}

Hair follicles of a male with a phosphoglycerate kinase deficiency, variant München (code $\mathrm{IV}_{14}$ in the genealogy of this German family (11)) were attached to adhesive tape, put into an Eppendorf reaction vial and send to the laboratory by air mail. As reference samples, hair follicles of a healthy control (control II in tab. 3 and 4) were plucked on the day of dispatch (stored dry at room temperature) and on the day of arrival of the mailed hair follicles.

\section{Results}

Optimal assay conditions for phosphoglycerate kinase activity in human hair follicles were achieved with $15 \mu \mathrm{l}$ hair follicle lysate (fig. $1 \mathrm{a}$ ) at a $\mathrm{pH}$ of 7.0 (fig. $1 \mathrm{~b}$ ). The reaction was found to be linear up to 20 minutes (fig. 1 c). All further experiments were performed under these conditions. The enzymatic nature of the reaction was further demonstrated by the low rate of nicotinamide adenine dinucleotide (reduced form) conversion:

a) when boiled hair follicle lysate was used;

b) when the incubation was carried out at $4{ }^{\circ} \mathrm{C}$;

c) when the incubation was carried out in the $a b$ sence of 3-phosphoglycerate (tab. 1).

Glucose-6-phosphate dehydrogenase was used as a reference enzyme to compensate for differences in hair follicle size and quality, since it is measurable in single hair follicle lysate (9), and its distribution pat- 

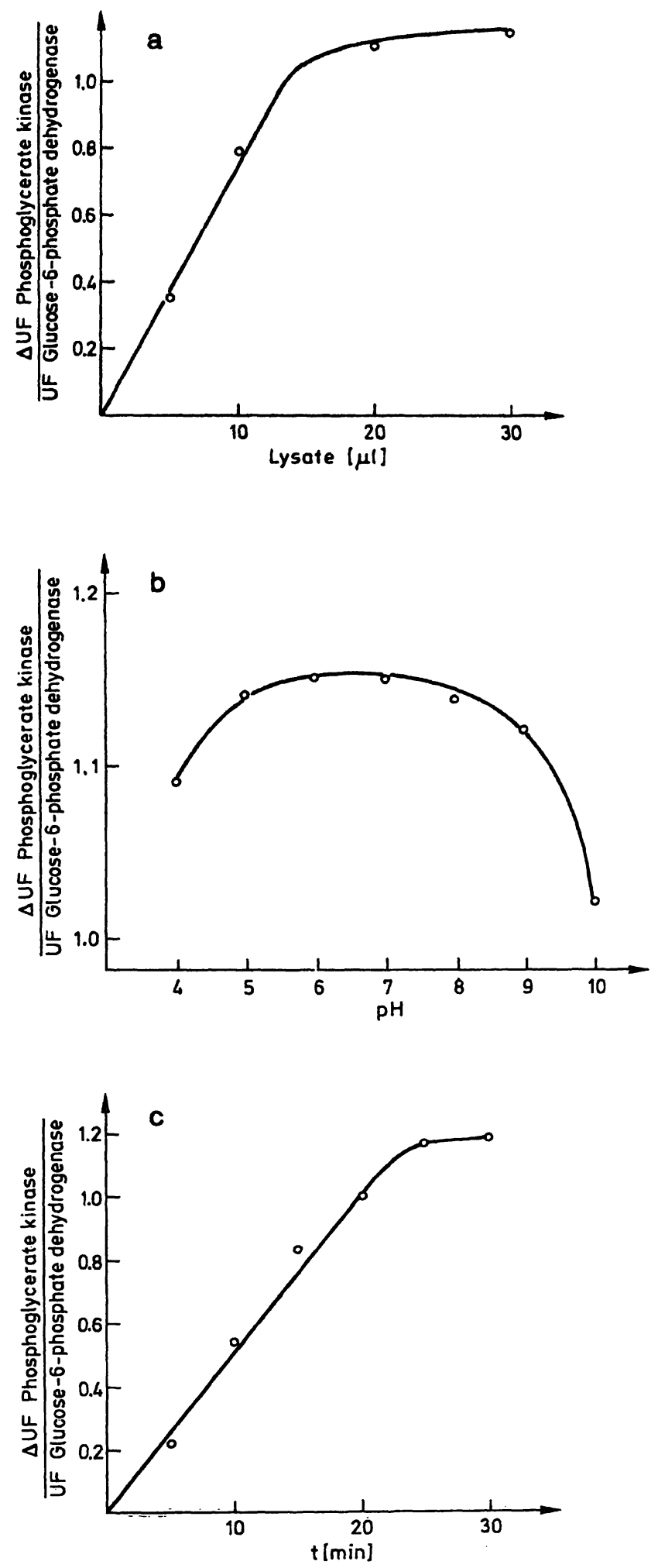

Fig. 1. Determination of the optimal assay conditions for phosphoglycerate kinase in human hair follicles. All data are expressed as the mean ratio of phosphoglycerate kinase activity versus glucose-6-phosphate dehydrogenase activity $(n=10)$. U.F. $=$ arbitrary units of fluorescence.

a) Relationship between the volume of lysate added and velocity (20 minutes incubation, $\mathrm{pH} 7.0$ )

b) Relationship between $\mathrm{pH}$ and velocity ( 20 minutes incubation, $15 \mu \mathrm{l}$ hair follicle lysate)

c) Relationship between incubation time and velocity (15 $\mu$ l hair follicle lysate, $\mathrm{pH} 7.0$ )
Tab. 1. Phosphoglycerate kinase in human hair follicle lysate using different incubation systems (mean \pm standard deviation).

\begin{tabular}{ll}
\hline Incubation system & $\begin{array}{l}\text { Relative enzyme } \\
\text { activity }\end{array}$ \\
\hline $\begin{array}{l}\text { Incubation as described in } \\
\text { Materials and Methods }\end{array}$ & $1.00 \pm 0.01$ \\
$\begin{array}{l}\text { Incubation in the absence of } \\
\text { 3-phosphoglyceric acid }\end{array}$ & $0.03 \pm 0.03$ \\
$\begin{array}{l}\text { Incubation at } 4^{\circ} \mathrm{C} \\
\text { Incubation using boiled lysatc }\end{array}$ & $0.20 \pm 0.06$ \\
\hline
\end{tabular}

tern in hair follicles is very similar to that of phosphoglycerate kinase (tab. 2). In some areas of the world (not in northern and western Europe) glucose6-phosphate dehydrogenase deficiency occurs frequently. In these cases another reference enzyme, for which the information is coded on an autosomal chromosome, is preferred. 6-Phosphogluconatc dehydrogenase meets this criterion and its determination is relatively simple. Determination of phosphoglycerate kinase, glucose-6-phosphate dehydrogenase and 6phosphogluconate dehydrogenase in 100 individual hair follicles from 10 healthy volunteers showed the advantage of using the ratio between phosphoglycerate kinase and a reference enzyme: the variation in phosphoglycerate kinase activity (highest value / lowest value between individual hair follicles is 2.8) is improved by relating phosphoglycerate kinase to glucose-6-phosphate dehydrogenase (highest value / lowest value is 2.0) or 6-phosphogluconate dehydrogenase (highest value / lowest value is 2.4).

Table 3 summarizes the results for phosphoglycerate kinase and glucose-6-phosphate dehydrogenase activities, and table 4 summarizes the results for phosphoglycerate kinase and 6-phosphogluconate dehydrogenase activities in these 10 healthy individuals. The mean enzyme ratio is comparable in all volunteers and the highest versus the lowest mean value is only 1.6 .

Tab. 2. Relative distribution of enzyme activity ( \pm standard deviation) in hair follicles after microdissection.

\begin{tabular}{llll}
\hline & $\begin{array}{l}\text { Phospho- } \\
\text { glycerate } \\
\text { kinase }\end{array}$ & $\begin{array}{l}\text { Glucose-6- } \\
\text { phosphate } \\
\text { dehydro- } \\
\text { genase }\end{array}$ & $\begin{array}{l}\text { 6-Phospho- } \\
\text { gluconate } \\
\text { dehydro- } \\
\text { genase }\end{array}$ \\
\hline $\begin{array}{l}\text { Upper sheath } \\
(\mathbf{n}=15)\end{array}$ & $0.19 \pm 0.02$ & $0.25 \pm 0.04$ & $0.42 \pm 0.03$ \\
$\begin{array}{l}\text { Lower sheath } \\
(\mathbf{n}=15)\end{array}$ & $0.40 \pm 0.02$ & $0.33 \pm 0.03$ & $0.32 \pm 0.02$ \\
$\begin{array}{l}\text { Bulb } \\
(\mathbf{n}=15)\end{array}$ & $0.41 \pm 0.02$ & $0.42 \pm 0.05$ & $0.26 \pm 0.02$ \\
\hline
\end{tabular}


Tab. 3. Phosphoglycerate kinase and the glucose-6-phosphate dehydrogenase activities in ten volunteers (mean value \pm standard deviation of ten determinations).

\begin{tabular}{llll}
\hline Control & $\begin{array}{l}\text { Phosphoglycerate } \\
\text { kinase*) }\end{array}$ & $\begin{array}{l}\text { Glucose-6-phosphate } \\
\text { dehydrogenase**) }\end{array}$ & $\begin{array}{c}\text { Phosphoglycerate kinase } \\
\text { Glucose-6-phosphate dehydrogenase }\end{array}$ \\
\hline I & $1109 \pm 208$ & $1467 \pm 54$ & $0.76 \pm 0.12$ \\
II & $1190 \pm 236$ & $1410 \pm 86$ & $0.84 \pm 0.14$ \\
III & $1484 \pm 322$ & $1560 \pm 212$ & $0.94 \pm 0.17$ \\
IV & $1444 \pm 233$ & $1488 \pm 51$ & $0.97 \pm 0.13$ \\
V & $1606 \pm 262$ & $1617 \pm 166$ & $1.02 \pm 0.12$ \\
VI & $1613 \pm 108$ & $1583 \pm 69$ & $1.03 \pm 0.05$ \\
VII & $1626 \pm 105$ & $1574 \pm 69$ & $1.04 \pm 0.11$ \\
VIII & $1588 \pm 195$ & $1521 \pm 82$ & $1.05 \pm 0.12$ \\
IX & $1552 \pm 131$ & $1473 \pm 68$ & $1.18 \pm 0.05$ \\
X & $1720 \pm 78$ & $1456 \pm 59$ &
\end{tabular}

*) Expressed as the decrease in arbitrary units of fluorescence from the conversion of NADH to NAD ${ }^{+}$.

**) Expressed as the increase in arbitrary units of fluorescence from the conversion of NADP ${ }^{+}$to NADPH.

Tab. 4. Phosphoglycerate kinase and the 6-phosphogluconate dehydrogenase activities in ten volunteers (mean value \pm standard deviation of ten determinations).

\begin{tabular}{llll}
\hline Control & $\begin{array}{l}\text { Phosphoglycerate } \\
\text { kinase*) }\end{array}$ & $\begin{array}{l}\text { 6-Phosphogluconate } \\
\text { dehydrogenase*) }\end{array}$ & $\begin{array}{c}\text { Phosphoglycerate kinase } \\
\text { 6-Phosphogluconate dehydrogenase }\end{array}$ \\
\hline I & $1033 \pm 265$ & $323 \pm 56$ & $3.22 \pm 0.58$ \\
II & $985 \pm 307$ & $345 \pm 58$ & $2.84 \pm 0.76$ \\
III & $1598 \pm 418$ & $333 \pm 113$ & $4.85 \pm 0.56$ \\
IV & $1420 \pm 345$ & $332 \pm 122$ & $3.42 \pm 0.66$ \\
V & $1616 \pm 316$ & $423 \pm 149$ & $4.16 \pm 0.70$ \\
VI & $1422 \pm 297$ & $340 \pm 63$ & $3.76 \pm 0.71$ \\
VII & $1718 \pm 76$ & $478 \pm 117$ & $3.71 \pm 0.59$ \\
VIII & $1574 \pm 273$ & $422 \pm 49$ & $3.50 \pm 0.62$ \\
IX & $990 \pm 281$ & $274 \pm 53$ & $4.22 \pm 0.56$ \\
X & $1556 \pm 268$ & $368 \pm 69$ &. .50 \\
\hline
\end{tabular}

*) Expressed as the decrease in arbitrary units of fluorescence from the conversion of NADH to NAD+.

**) Expressed as the increase in arbitrary units of fluorescence from the conversion of NADP+ to NADPH.

The effect of storage on human hair follicles at room temperature for a period of 18 days is shown in table 5 and it can be concluded that all three enzymes show similar stability during a period of one week, resulting in a constant enzyme ratio.

In table 6 values are shown for the phosphoglycerate kinase to glucose-6-phosphate dehydrogenase ratios, and the phosphoglycerate kinase to 6-phosphogluconate dehydrogenase ratios in mailed hair follicles of a male with a phosphoglycerate kinase deficiency and in hair follicles of a healthy control person.
Tab. 5. Effect of storage on human hair follicle phosphoglycerate kinase, glucose-6-phosphate dehydrogenase and 6phosphogluconate dehydrogenase.

\begin{tabular}{|c|c|c|c|}
\hline \multirow{2}{*}{$\begin{array}{l}\text { Storage } \\
\text { (days) }\end{array}$} & \multicolumn{3}{|c|}{ Relative activity } \\
\hline & $\begin{array}{l}\text { Phospho- } \\
\text { glycerate } \\
\text { kinase }\end{array}$ & $\begin{array}{l}\text { Glucose-6- } \\
\text { phosphate } \\
\text { dehydrogenase }\end{array}$ & $\begin{array}{l}\text { 6-Phospho- } \\
\text { gluconate } \\
\text { dehydrogenase }\end{array}$ \\
\hline 0 & 1.00 & 1.00 & 1.00 \\
\hline 4 & 0.92 & 0.90 & 0.88 \\
\hline 7 & 0.84 & 0.85 & 0.79 \\
\hline 11 & 0.66 & 0.75 & 0.64 \\
\hline 14 & 0.61 & 0.70 & 0.56 \\
\hline 18 & 0.38 & 0.60 & 0.48 \\
\hline
\end{tabular}

Tab. 6. Values ( \pm standard deviation) for the ratios, phosphoglycerate kinase / glucose-6-phosphate dehydrogenase and phosphoglycerate kinase / 6-phosphogluconate dehydrogenase in mailed hair follicles of a male with phosphoglycerate kinase deficiency (type München) versus hair follicles of a control person.

$\frac{\text { Phosphoglycerate kinase }}{\text { Glucose-6-phosphate dehydrogenase }} \frac{\text { Phosphoglycerate kinase }}{\text { 6-Phosphogluconate dehydrogenase }}$

\begin{tabular}{lll}
\hline Control II (freshly isolated hair follicles) & $0.78 \pm 0.12$ & $3.18 \pm 0.45$ \\
Control II (stored hair follicles) & $1.17 \pm 0.33$ & $2.91 \pm 1.00$ \\
Phosphoglycerate kinase deficiency & $0.21 \pm 0.16$ & $0.69 \pm 0.47$ \\
München IV $_{14}$ & &
\end{tabular}




\section{Discussion}

In the present paper it is demonstrated that phosphoglycerate kinase activity can be accurately determined in single hair follicles and glucose-6-phosphate dehydrogenase or 6-phosphogluconate dehydrogenase can serve as a reference enzyme to compensate for differences in hair follicle size and quality.

Storage of hair follicles at room temperature and normal humidity results in only a minor loss of phosphoglycerate kinase, glucose-6-phosphate dehydrogenase and 6-phosphogluconate dehydrogenase activity during 7 days (tab. 5). As a consequence the enzyme ratios were almost unaffected. The latter allows hair follicles to be mailed without special care to laboratories for the measurement of phosphoglycerate kinase activity.

Although no tissue has yet been found in which phosphoglycerate kinase deficiency is not expressed (13), the final proof of the usefulness of hair follicles in this respect can only be made by verification in patients. As shown in tab. 6, the average values for the phosphoglycerate kinase to glucose-6-phosphate dehydrogenase ratios, and phosphoglycerate kinase to 6-phosphogluconate dehydrogenase ratios in mailed hair follicles of a male with a phosphoglycerate kinase deficiency (phosphoglycerate kinase München) are only $25 \%$ of the ratios for a healthy control person (Control II in tab. 3 and 4, with the lowest measured enzyme ratio), and no overlap of values was observed. This demonstrates that phosphoglycerate kinase deficiency is also expressed in human hair follicles.

\section{References}

1. Valentine, W. N., Hsieh, H., Paglia, D. E., Anderson, H. M., Baughan, M. A., Jaffé, E. R. \& Carson, O. M. (1969) N. Engl. J. Med. 280, 528-534.

2. Konrad, P. N., McCarthy, D. J., Mauer, A. M., Valentine, W. N. \& Paglia, D. E. (1973) J. Pediati. 82, 456-460.

3. Doxiades, S. A., Fessas, Ph. \& Valaes, T. (1961) Lancet $i$, 297-301.

4. Beutler, E. (1975) A Manual of Biochemical Methods $2^{\text {nd }}$ ed., Grune \& Stratton, New-York.

5. Deys, B. F., Grzeschick, K. H., Grzeschick, A., Jaffé, E. R. \& Siniscalco, M. (1972) Science 175, 1002-1003.

6. Lyon, M. F. (1961) Nature (London) 190, 372.

7. Gartler, S. M., Scott, R. C., Goldstein, J. L., Cambell, B. \& Sparkes, R. (1971) Science 172, 572.

8. Vermorken, A. J. M., Weterings, P. J. J. M., Spierenburg, G. Th., van Bennekom, C. A., Wirtz, P., de Bruyn, C. H. M. M. \& Oei, T. L. (1978) Br. J. Dermatol. 98, 191-196.
Previous studies have shown that human hair follicles are advantageous for the carrier detection of several $\mathrm{X}$-linked enzyme disorders $(7,8,9)$. As a result of the clonal origin of hair follicles, lyonisation of the $\mathrm{X}$-chromosome will present a mosaic of normal and deficient values. Due to the fact that the phosphoglycerate kinase to glucose-6-phosphate dehydrogenase ratio (tab. 3) and the phosphoglycerate kinase to 6-phosphogluconate dehydrogenase ratio (tab. 4) is fairly constant between normal individuals, it should be possible with this method to detect heterozygous carriers since deficient phosphoglycerate kinase values range from $5 \%$ of the normal activity (phosphoglycerate kinase Creteil (3)) up to $20-25 \%$ (phosphoglycerate kinase München (11) and phosphoglycerate kinase Uppsala (13)). The theoretical percentage of completely deficient hair follicles in heterozygous carriers is $12.5 \%$, assuming that the hair follicles are derived from three progenitor cells and that a random and equal distribution of mutant and normal cells takes place (14). It should therefore suffice to determine the phosphoglycerate kinase activity in 20-30 hair follicles, in order to identify heterozygous carriers.

\section{Acknowledgement}

The authors wish to thank Prof. Dr. W. K. G. Krietsch, Institute for Physiological Chemistry and Physical Biochemistry, University of München, (FRG) for his cooperation in obtaining hair follicles of a male with a phosphoglycerate kinase deficiency.
9. Miguel, A., Ramon, M., Petitpierre, E., Goos, C. M. A. A., Vermeesch-Markslag, A. M. G. \& Vermorken, A. J. M. (1983) Hum. Genet. 64, 176-179.

10. Vermorken, A. J. M., Wirtz, P., Spierenburg, G. Th., van Bennekom, C. A. \& de Bruyn, C. H. M. M. (1979) J. Clin. Chem. Clin. Biochem. 17, 325-329.

11. Krietsch, W. K., Krietsch, H., Kaiser, W., Duennwald, M., Kuntz, G. W., Duhm, J. \& Bücher, T. (1977) Eur. J. Clin. Invest. $7,427-435$.

12. Hjelm, M., Wadam, B. \& Yoshida, A. (1980) J. Lab. Clin. Med. 96, 1015-1021.

13. Svirklys, L. G. \& O'Sullivan, W. J. (1980) Clin. Chim. Acta $108,309-315$.

14. Dancis, J., Silvers, D. N., Balis, M. E., Cox, R. P. \& Schwartz, M. S. (1981) Hum. Genet. 58, 414-416.

Dr. A. J. M. Vermorken

Research Unit for Cellular Differentiation and Transformation

University of Nijmegen

Geert Grooteplein Noord 21

NL-6525 EZ Nijmegen 
: 